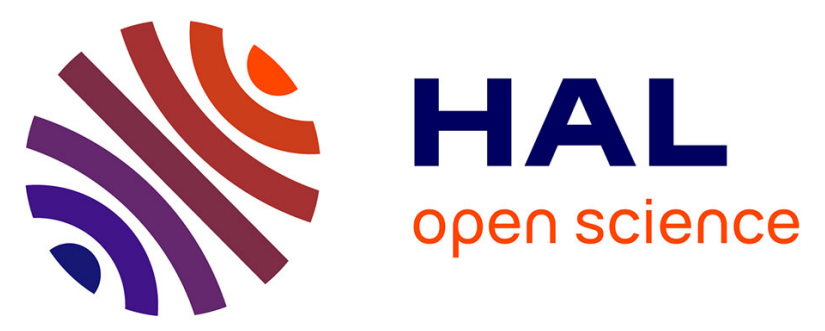

\title{
Late Holocene relative sea-level fluctuations and crustal mobility at Bataneh (Najirum) archaeological site, Persian Gulf, Iran
}

Majid Pourkerman, Nick Marriner, Christophe Morhange, Morteza Djamali, Hamid Lahijani, Sedighe Amjadi, Matteo Vacchi, Mohammad Jelodar, Giorgio Spada, Hossein Tofighian, et al.

\section{To cite this version:}

Majid Pourkerman, Nick Marriner, Christophe Morhange, Morteza Djamali, Hamid Lahijani, et al.. Late Holocene relative sea-level fluctuations and crustal mobility at Bataneh (Najirum) archaeological site, Persian Gulf, Iran. Geoarchaeology: An International Journal, 2021, 36 (5), pp.740-754. 10.1002/gea.21860 . hal-03196961

\section{HAL Id: hal-03196961 \\ https://hal-amu.archives-ouvertes.fr/hal-03196961}

Submitted on 27 Apr 2021

HAL is a multi-disciplinary open access archive for the deposit and dissemination of scientific research documents, whether they are published or not. The documents may come from teaching and research institutions in France or abroad, or from public or private research centers.
L'archive ouverte pluridisciplinaire HAL, est destinée au dépôt et à la diffusion de documents scientifiques de niveau recherche, publiés ou non, émanant des établissements d'enseignement et de recherche français ou étrangers, des laboratoires publics ou privés. 


\title{
Late Holocene relative sea-level fluctuations and crustal mobility at Bataneh (Najirum) archaeological site, Persian Gulf, Iran
}

\author{
Majid Pourkerman $^{1,2}$ (1) | Nick Marriner ${ }^{3}$ | Christophe Morhange ${ }^{1}$ | \\ Morteza Djamali $^{4}$ | Hamid Lahijani ${ }^{2}$ | Sedighe Amjadi ${ }^{2,5}$ | Matteo Vacchi ${ }^{6}$ | \\ Mohammad E. Jelodar ${ }^{7}$ | Giorgio Spada ${ }^{8}$ | Hossein Tofighian ${ }^{9}$ \\ Abdolmajid N. Beni ${ }^{2}$ ()
}

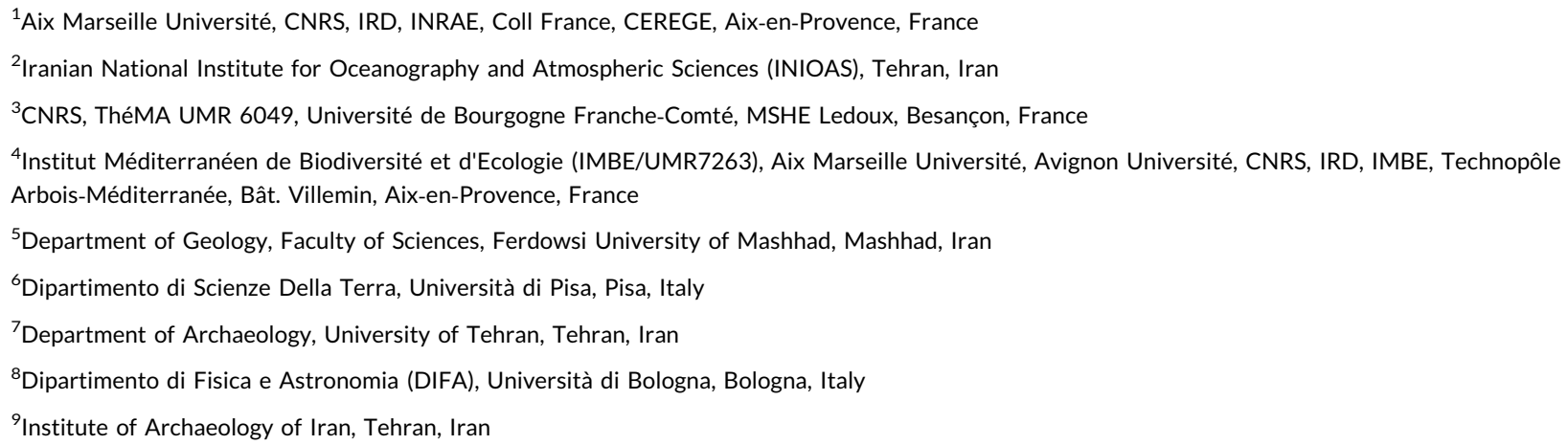

\section{Correspondence}

Majid Pourkerman, No. 3, Etemad Zadeh St., Fatemi Ave., Tehran 1411813389, IR. Iran.

Email: Pourkerman@yahoo.com

Nick Marriner, CNRS, ThéMA UMR 6049, Université de Bourgogne Franche-Comté, MSHE Ledoux, 32 rue Mégevand, Besançon Cedex 25030, France.

Email: nick.marriner@univ-fcomte.fr

Scientific editing by Noémi Müller.

\section{Funding information}

Ministero dell'Istruzione, dell'Universita`e della Ricerca; Finanziamento delle At- tivita Base di Ricerca; Centre National de Recherche Scientifique; Labex OT-Med; French Embassy in Iran, Campus France; Iran National Science Foundation; International Scientific Studies and Collaborations

\begin{abstract}
The impacts of relative sea-level (RSL) variations and crust mobility on the development of ancient harbours in the northern Persian Gulf are poorly understood. Many unanswered questions remain with regard to the main reasons for a shift in the location of the most important ancient harbours in the northern part of the Persian Gulf coastal since $50 \mathrm{BC}$. Furthermore, some important early Islamic harbours, such as Siraf, have ancient city quarters that are today below the present sea level. The aim of this study is to evaluate the relationship between halokinesis and RSL changes using geophysical models and multidisciplinary geoarchaeological methods at the ancient Sassanid-Islamic site of Bataneh (presently known as Najirum) located at the foothill of an active Darang salt diapir. The results reveal that after the mid-Holocene highstand, RSL regression was not continuous. The studied facies have recorded three RSL oscillations. The oscillations are correlated with the eustatic sea-level position. During the first lowstand, important Sassanid harbours shifted from Rishar to Apologus. The second lowstand is consistent with the transition of maritime trade from Apologus to Siraf, during the Abbasid dynasty. Uplift of the Bataneh coastal zone exposed the city to risks from flooding and fluvial debris flows. With a modification of the local watershed, runoff water originating
\end{abstract}


from the salt anticlinal was controlled and used for the extraction of gypsum in evaporation ponds. The economic expansion of Siraf led to Bataneh being abandoned with a shift in trade to Kish Island.

\section{KEYWORDS}

ancient harbour, crustal mobility, geoarchaology, Najirum, Persian Gulf, relative sea level

\section{1 | INTRODUCTION}

The Persian Gulf is located between the Zagros Mountains to the northwest and the Arabian Platform to the southeast. Collision of the Arabian and Eurasian continents played out during the Tertiary. At the end of the Oligocene, the opening of the Red Sea separated Arabia from Africa and produced an uplift of the Arabian Shield, exposing the Precambrian crystalline basement. The main fault systems trend N-S from the Qatar Arc and the SE boundary of the shield. During the evolution of the Zagros orogenic system, evolution of the Arabian Plate was flexed, leading to the formation of the Mesopotamian foreland basin and the Persian Gulf in front of the Zagros Mountains (Konert et al., 2001). The asymmetry of the Persian Gulf has been accentuated due to the tilting of the Arabian Peninsula, associated with an opening of the Red Sea in the Neogene. Zagros is one of the most active collisional belts in the world, and much of the deformation and seismicity of the Zagros Mountains and high-relief topography on the northeastern margin of the Persian Gulf are related to its active tectonics. On the southern margin of the Gulf, the aseismic low relief is consistent with a tectonically static region (US Geological Survey, 2011).

The Zagros tectonic setting and halokinesis control the Persian Gulf basin and its coastal morphology. According to Pourkerman et al. (2020) classification, the Persian Gulf coast can be subdivided into three morphological zones with different tide levels: (i) gently sloping marshland coasts with permanent rivers (Zone 1); (ii) diapiric uplifting coastal salt domes (Zone II) and (iii) rocky coasts with steep coastal slopes (Zone III) (Figure 1 and Table 1).

Several studies have been carried out in the Persian Gulf to reconstruct Holocene relative sea-level (RSL) changes (Aqrawi, 2001; Kassler, 1973; Lambeck, 1996; Lokier et al., 2015; McClure \& Vita-Finzi, 1982; Paul \& Lokier, 2017; Williams \& Walkden, 2002). Uchupi et al. (1999) suggested that the Holocene marine transgression has accelerated basin subsidence in the axial zone and that local uplift occurred, especially in the northeast of the Persian Gulf. Coastal uplift in the United Arab Emirates happened under the influence of Holocene RSL rise and halokinesis (Wood et al., 2012). By contrast, Stevens et al. (2014) believed that RSL in the southeast of the Persian Gulf is controlled by eustatic sea-level changes and that local halokinesis and neo-tectonics have not had any impacts on RSL and coastal elevation changes.

An understanding of ancient maritime trade in the Persian Gulf must be based on a proper contextualisation of the physical factors involved in shipping goods from one place to another (Caspers, 1971). Without consideration of the main physical parameters, involving maritime navigation and port facilities, such as wind and surface current regimes, RSL history, climate changes and tectonic settings, it is not possible to fully grasp maritime trade and ancient harbours. Therefore, multidisciplinary geoarchaeological studies of ancient harbours and maritime structures help to understand the role of palaeoenvironmental changes in maritime trade activities and ancient civilisations (e.g., Benjamin et al., 2017; Marriner, Kaniewski, et al., 2017; Marriner \& Morhange, 2007; Marriner, Morhange, et al., 2017; Marriner et al., 2010; Morhange et al., 2001; Pourkerman et al., 2020; Vacchi et al., 2020). The most important ancient harbours in the Persian Gulf were located on the Iranian coast until the 20th century $A D$ (Potter, 2009). Coastal cabotage and the location of ancient harbours in the Persian Gulf were partly controlled by RSL changes, coastal morphology, the meteo-marine context (e.g., Shamal winds) and sea-surface currents (Pourkerman et al., 2020).

\section{I MARITIME TRADE HISTORY IN THE PERSIAN GULF}

The first evidence of maritime trade in the Persian Gulf dates back to the 3rd millennium BC. The archaeological remains attest to trade connections between both Mesopotamian and Indus civilisations (Caspers, 1971). Between 247 BC and 224 AD, the Parthian Empire ruled over local kingdoms in both the northern and southern Persian Gulf to exploit the Silk Road trade via maritime routes (Daryaee, 2009). Maritime trade continued under the Sassanid empires. The Sassanians sought to gain control of the Persian Gulf for both political and economic aspirations. Daryaee (2009) believed that the Sasanians saw the Persian Gulf as their mare nostrum and part of Iranshahr, or the 'Domain of the Iranians'. A flourishing maritime trade between the Persians and the Romans reduced the amount of traffic on the Silk Road (Potter, 2009). The foundation of Najirum dates back to the Sassanid Empire (Al-Istakhri, 1870). It is classified as a sector of Siraf in the Ardeshir Khooreh ('Khooreh' means 'province' in Persian). The Ardeshir Khooreh was one of the largest provinces between the five main united provinces of Fars (Al-Istakhri, 1870). The southern part of the province was demarcated by the Persian Gulf coast. As it was adjacent to the central Sassanid Empire, and due to the importance of maritime trade activities at this time, Ardeshir Khooreh became one of the most important provinces. 

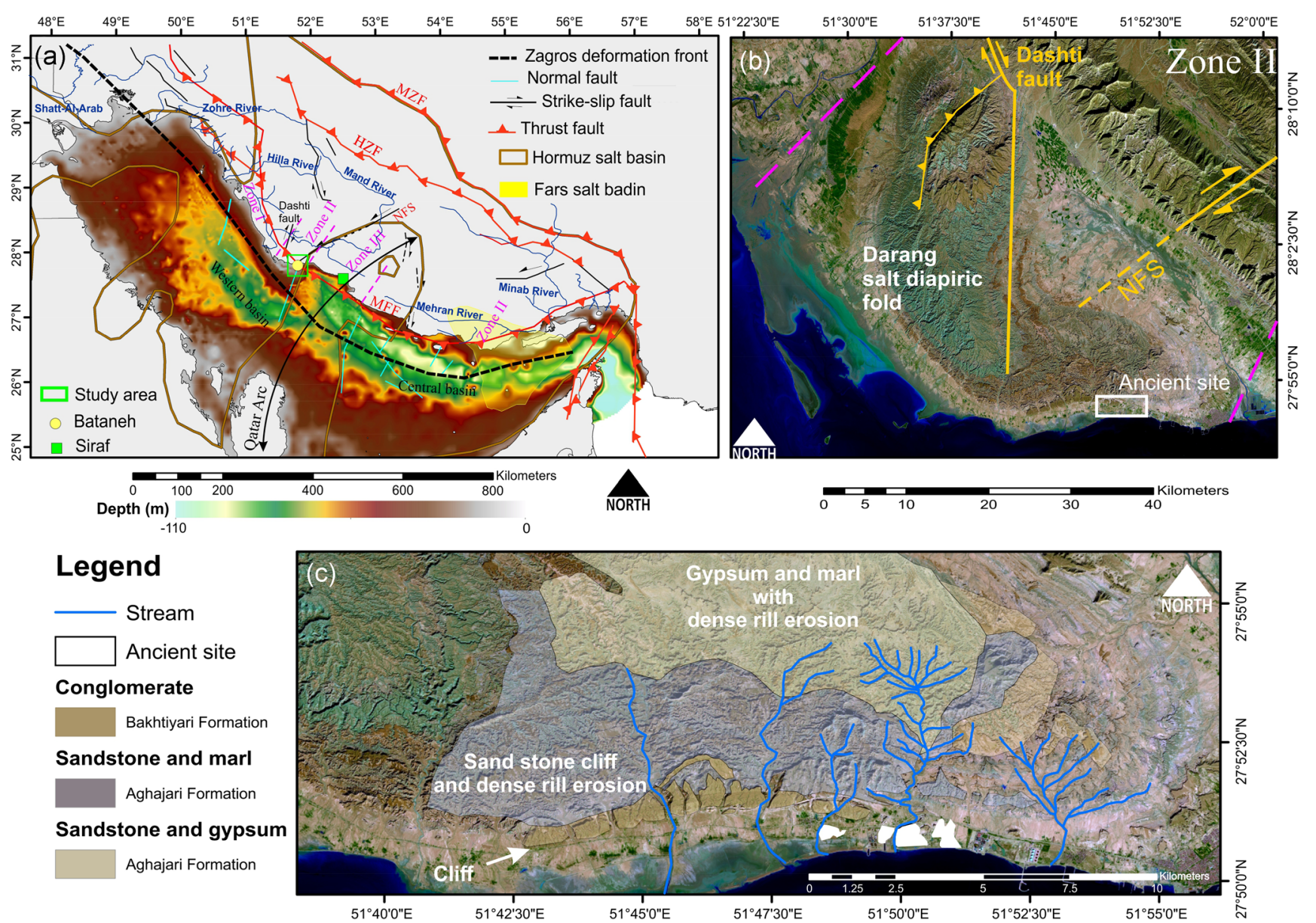

FIGURE 1 (a) The Persian Gulf bathymetry, coastal geomorphological classification and major structural elements of the Zagros fold-and-thrust belt (modified after Berberian, 1995; Hassanpour et al., 2020; Jahani et al., 2017; Jiménez-Munt et al., 2012; Pourkerman et al., 2020). HZF, High Zagros Fault; MFF, Mountain Front Flexure; MZF, Main Zagros Fault; NFS, Nezamabad Fault system. (b) Position of the ancient site at the Darang salt diapiric fold on a Landsat 8 image (RGB = 753), position of N-S Dashti and NE-SW Nezamabad fault systems. (c) Lithological units [Color figure can be viewed at wileyonlinelibrary.com]

The first acceleration in maritime trade in the Persian Gulf happened during late Antiquity when the connection between Fars and East Asia created conflicts between the Persians and the Romans (Daryaee, 2003). According to historical texts such as
Tabari, Al-Istakhri, Ibn Hawqal and Al-Mas'udi (Al-Istakhri, 1870; Al-Mas'udi, 1962; Ibn, 1873; Tabari, 1987), maritime trade flourished again during the 9 th and 10 th centuries AD. Siraf (the main port) and Najirum (a subsidiary) played key roles in facilitating maritime

TABLE 1 Geomorphological zonation and tidal levels at sites from the Strait of Hormuz to Shatt-al-Arab

\begin{tabular}{|c|c|c|c|c|c|c|c|c|}
\hline \multirow[b]{2}{*}{ Tidal gauge station } & \multirow[b]{2}{*}{ Ancient site } & \multirow[b]{2}{*}{ Latitude $\mathrm{N}$} & \multirow[b]{2}{*}{ Longitude $\mathrm{E}$} & \multicolumn{4}{|c|}{ Height in metres above datum } & \multirow[b]{2}{*}{ Class } \\
\hline & & & & $\overline{\mathrm{MHHW}}$ & MLHW & MHLW & MLLW & \\
\hline Bandar-e Abbas & Unknown & $29^{\circ} 22^{\prime}$ & $56^{\circ} 17^{\prime}$ & 3.4 & 2.6 & 1.4 & 0.7 & Zone II \\
\hline Dayyer & Bataneh (Najirum) & $27^{\circ} 50^{\prime}$ & $51^{\circ} 56^{\prime}$ & 2.0 & 1.6 & 0.8 & 0.5 & Zone II \\
\hline Bandar-e Bushehr & Rishar & $28^{\circ} 54^{\prime}$ & $50^{\circ} 45^{\prime}$ & 1.9 & 1.3 & 1.1 & 0.5 & Zone I \\
\hline Imam Hassan & Ceniz & $29^{\circ} 50^{\prime}$ & $50^{\circ} 15^{\prime}$ & 2.4 & 1.7 & 1.3 & 0.6 & Zone I \\
\hline Shatt-al-Arab & Apologus & $29^{\circ} 50^{\prime}$ & $48^{\circ} 43^{\prime}$ & 3.0 & 2.4 & 1.3 & 0.4 & Zone I \\
\hline
\end{tabular}

Abbreviations: MHHW, mean higher high water; MHLW, mean higher low water; MLHW, mean lower high water; MLLW, mean lower low water. 
navigation for ocean-going vessels. For the first time in history, regular trade between merchants from the Persian Gulf and India, Southern Asia, South Arabia and East Africa was initiated. In fact, Siraf was a redistribution centre linked to Basra (Abbasid caliphate capital). At this time, Siraf became the wealthiest settlements in the region (Priestman, 2007). The prosperity of Siraf during Sassanian and early Islamic times (apogee of the port) is confirmed by zooarchaeological studies (Driesch \& Dockner, 2002). Results suggest that the number of animal species decreased from 133 during flourishing stages to 72 when Siraf lost its importance. By the 13th to 16 th centuries $A D$, a mere 39 species are recorded at Siraf.

After the decline of Siraf, the most important harbours shifted to the Persian Gulf Islands such as Kish (1000-1300 AD) and Hormuz (1300-1600 AD). Later, harbour activities returned to the coast at Bandar-e Abbas from 1622 to the mid-18th century and at Khurramshahr after about 1900 (Potter, 2009).

Although historical and archaeological studies shed light on the maritime trade history of the Persian Gulf, none of them can explain the reasons for important harbour displacements. In this study, we employ geoarchaeology to investigate the evolution of the ancient site of Bataneh (Najirum). The site was selected due to its location at the foothill of a salt diapiric fold to reconstruct RSL changes and the role of halokinesis in driving coastal changes.

\section{3 | SALT TECTONICS}

One of the most important features of the Zagros belt is the presence of several salt diapirs of Late Precambrian-Early Cambrian Hormuz salt that existed in the eastern part of the Zagros fault thrust belt and the Persian Gulf. Halokinesis started shortly after the deposition of the Hormuz salt in the early Paleozoic, and it has continued up to the present (Jahani et al., 2007). The salt domes generally existed along/near the N-S and NE-SW fault system (Jahani et al., 2017).

The central basin of the Persian Gulf is well known for several salt domes and diapiric folds along its coast (Kalat, Bostaneh, Mughu, Moallem, Homiran and Darang) and offshore islands (Great and small Tunb, Farur and Abu Musa) in Iran, the United Arab Emirates (Sir Abu Nuayer, Arzanah, Sir Bani Yas) and Qatar (Halul and Sharao) (Beydoun, 1991; Thomas et al., 2015). In the east of the central basin, salt tectonics is linked to the salt-bearing system of the Hormuz salt formation and late Oligocene-Early Miocene Fars salt (Figure 1) (Hassanpour et al., 2020). In the early Miocene, after the beginning of the Zagros continental collision, the Hormuz salt extrusion started again. Consequently, Fars salt diapirism was triggered by gravitational loading produced by an overriding of the allochthonous Hormuz salt sheet. This process pushed the Fars salt outwards (Snidero et al., 2020). The salt diapir close to the present coast of the Persian Gulf emerged after the reactivation of salt domes during the final Zagros folding phase (Jahani et al., 2007). The impacts of halokinesis on the coastal elevation of the United Arab Emirates has been discussed by Wood et al. (2012) and Lidour et al. (2020). But its effects on RSL and coastal dynamics in the northern Persian Gulf are still unknown.

The ancient site of Bataneh is located in the foothills of the Darang Anticline (diapiric fold, Zone II) (Figure 1b). The Darang salt pillow is located along the southern end of the Dashti Fault system with a N-S orientation (Figure 1). The Darang salt pillow started to grow in the Paleozoic, and this growth continued through geological time (Jahani et al., 2017). The diapiric fold has exposed lithological units with evaporation minerals such as gypsum and gypsum marl. The concentration of deep rill erosion features in the upland areas shows their high sensitivity to water erosion (Figure 1c). Bataneh has an open coastal morphology and a NW-SE longshore current responsible for coastal erosion and moving sandbars along the coast (Pourkerman et al., 2019).

\section{4 | GEOMORPHOLOGICAL FEATURES AND ARCHAEOLOGICAL CONTEXT}

According to field observations, the ancient site of Bataneh comprises four sectors separated by natural geomorphological features such as rocks, bays and flood plains. All of the ancient sites lie on high ground, 7-11 $\mathrm{m}$ above the present sea level. Several streams and ephemeral rivers are sourced in the evaporation unit; the largest one passes north of site B. Alluvial fans, floodplains and wadis are the most important geomorphological features, with a high potential risk of flooding and debris flows for archaeological remains (Figure 2).

Our knowledge about historic sites is limited to just two surveys conducted by Esmaeili Jelodar (2011) and Azarian (2013). Esmaeili Jelodar (2011) introduced three (A, B and C) ancient zones. He dated the sites to the late Sassanid-early Islamic period on the basis of a ceramics chronotypology. His study focused on Zone B due to the presence of features mentioned in historic texts, such as ancient mosques with staircases carved into the rock (Talle Ashrafi) to the north and an estuary to the west (Figure 3). A variety of ceramics and Chinese porcelains attest to a thriving city. The archaeological remains and spatial location of the ancient site (distance from Siraf) harbour have led archaeologists to identify the ancient site as the missing port town of Najirum.

The site is elevated 8-10 $\mathrm{m}$ above present sea level to the north. To the south, the elevation decreases with a gentle slope. An ephemeral river channel passes between Zones B and C. Five alluvial fans are located $200 \mathrm{~m}$ north of the ancient site, along two ephemeral rivers (Figure 2).

Although Zone $\mathrm{B}$ has been damaged by recent industrial constructions, Zones $A$ and $C$ contain three important types of artefacts. (i) The first artefact is an urban fabric containing several ancient walls and decorative gypsum objects. The building walls are made of rubble and baked gypsum. On the interior side, the walls are covered with plaster motifs. (ii) The second type of artefact is an artisanal area with remains of furnaces and (iii) the third one is an area of rectangular embankments (ponds) connected via an ancient canal (Figure 3). 


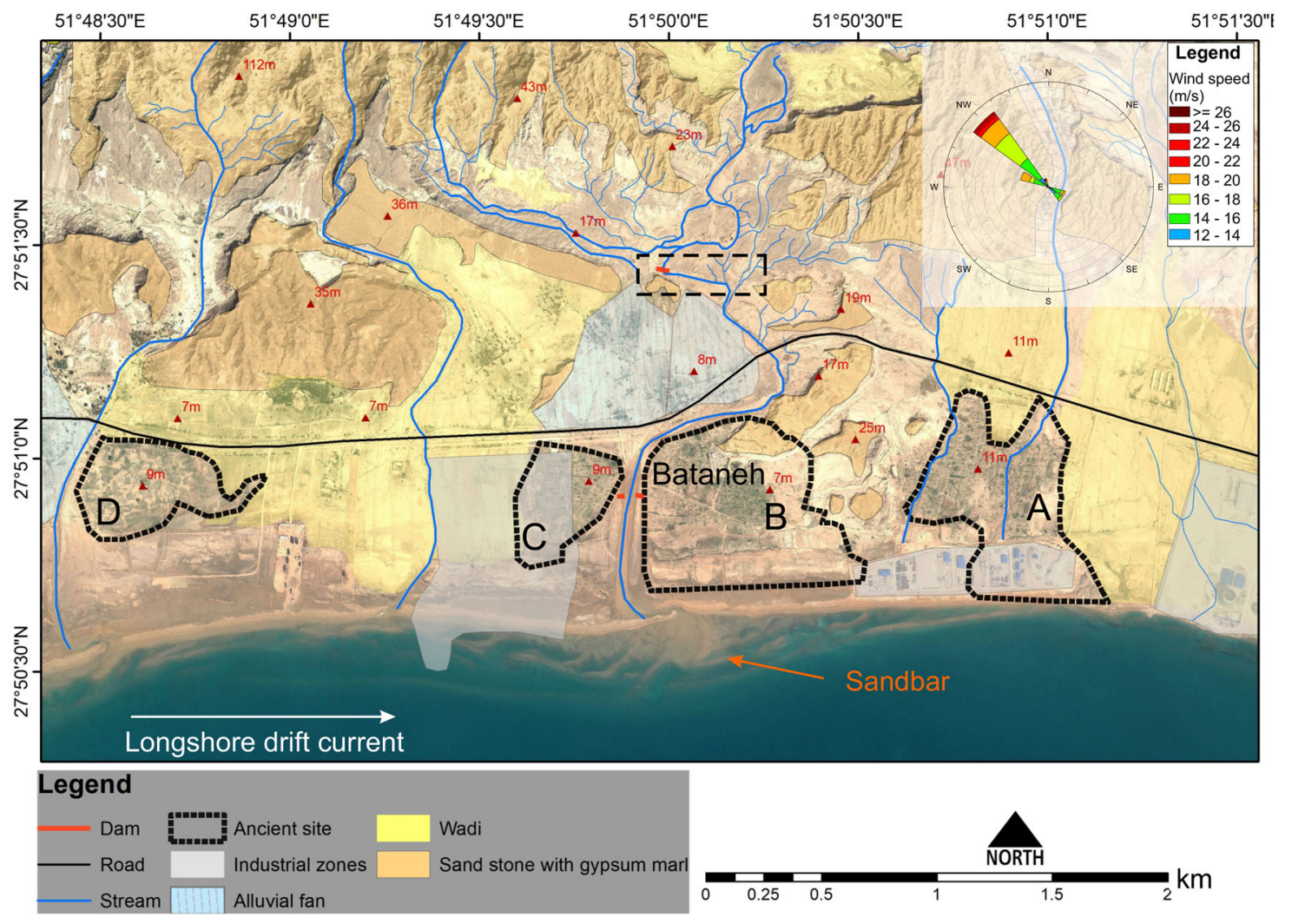

FIGURE 2 General geomorphological map of Bataneh and its ancient sites located on a Google Earth image (2011). Zones A, B and C are reported by Esmaeili Jelodar (2011) and Zone D is introduced in this study. The black dashed line denotes the location of a man-made dike and artificial watercourse for redirecting runoff water. The recent industrial constructions at site $C$ have been updated using a Landsat 8 panchromatic band (2020) [Color figure can be viewed at wileyonlinelibrary.com]

To the west of the city, two embankments have been erected along either bank of the stream, for channel stability. A trace of dikes is observed at the end of the walls to prevent water runoff to the sea. The eastern embankment is distinct, with the ancient canal that stretched along the ponds (Figure 3 ).

\section{5 | METHODOLOGY}

In this study, we integrated high-resolution CORONA, Google Earth and moderate-resolution Landsat $8 \mathrm{OLI}$ images (overpass frequencies of 16 days) to map the ancient site and its geomorphological features (Beck et al., 2007; Myers, 2010; Saleem et al., 2018), in addition to updating the most recent anthropogenic constructions over the historical site. The satellite images were georeferenced using 1:100,000 topographic maps from the National Cartographic Center (NCC) with a root mean square error (RMSE) between 0.01 and 0.05 pixels.

A 3-m borehole was extracted from sector (iii) Zone B, an area in which human disturbance was negligible. The core was levelled using a theodolite $(+4.5 \mathrm{~m})$ in relation to the present mean sea level (MSL). After core collection, nondestructive magnetic susceptibility (MS) was measured using a Bartington MS2C 100-mm diameter loop sensor with an MS2 metre at 2-cm resolution (Delile et al., 2014). Subsamples were obtained using the high-resolution sampling procedure described by Marriner and Morhange (2007). Subsamples were oven-dried at $50^{\circ} \mathrm{C}$ for $12 \mathrm{~h}$. Each sample was separated into three fractions for biostratigraphy, granulometry, organic matter (OM) and carbonate content. Wet sieving was performed using mesh sizes of $2 \mathrm{~mm}$ and 63 microns. After processing and oven-drying, the ostracods were picked from $10 \mathrm{~g}$ of $>125-\mu \mathrm{m}$ size fraction and placed on palaeontological slides to count and identify the species (Marriner et al., 2005). Simultaneously, microscopic sedimentary properties and general minerals were noted. Macrofossils ( $>2 \mathrm{~mm}$ ) were identified using the Persian Gulf data set described by Sahafi et al. (2000).

A geomorphological map of the most morphological features in the hinterland and coastal zones was created. The map helped to interpret the interactions between marine (subtidal, sand bar and coastal) and terrestrial (alluvial fans, marshland and flooding plain) facies and palaeoenvironmental changes. Surface sampling of coastal zones was performed to identify sedimentological properties and ostracods species (Marriner et al., 2005). The uncertain values for RSL were calculated according to the facies depth and species in relation to the present day. Uplift uncertainly was also evaluated according to the field elevation measurement errors and sediment compaction during drilling. 


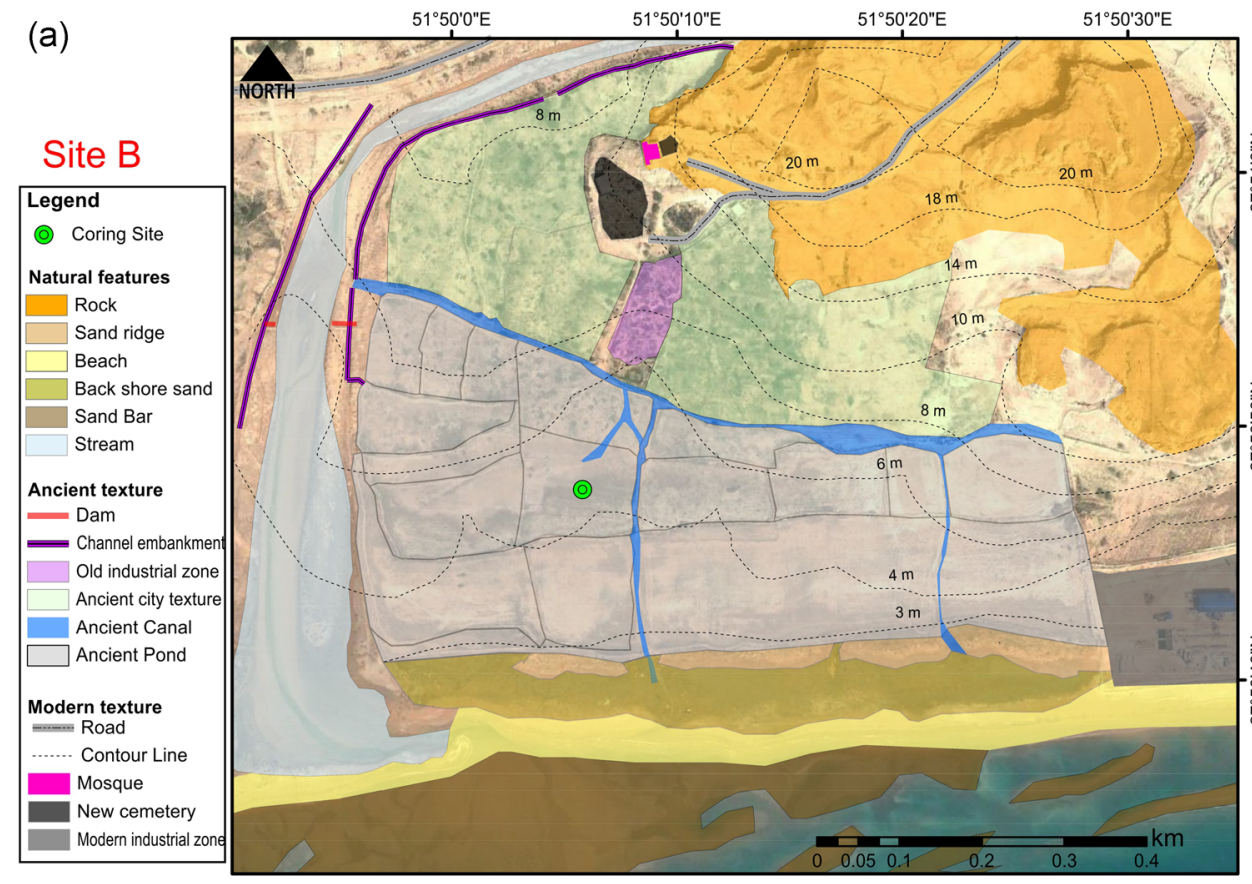

(e)


FIGURE 3 (a) General geomorphological features of Zone B and sectors of the ancient city of Bataneh. The green point indicates the coring site. (b) Remnants of the ancient city wall, comprising rubble and baked gypsum. (c) Remains of an ancient furnace in the old industrial area (purple zone). (d) Several samples showing the use of baked gypsum for decorative elements and (e) plaster motifs [Color figure can be viewed at wileyonlinelibrary.com]

Laser granulometry was performed using a Horiba La950E after treatment of sediments by peroxide hydrogen and $\mathrm{HCL} 0.1$ to remove the effects of biological production on the sedimentary textures. The sediments were classified according to Folk (1954). Ternary diagrams and statistical parameters were calculated by the method of moments (Folk \& Ward, 1957). Organic matter (OM) and carbonate properties were calculated using loss on ignition at $550^{\circ} \mathrm{C}$ and $950^{\circ} \mathrm{C}$ (Heiri et al., 2001).

According to the main facies changes and anthropogenic horizons, three ${ }^{14} \mathrm{C}$ dates were undertaken at the Poznan Radiocarbon Laboratory, mainly on charcoal and juvenile bivalve shells due to the absence of organic matter. The data were calibrated using CALIB 8.1, with a marine delta reservoir specific to the Persian Gulf (Southon et al., 2002) (Table 2).

The glacial isostatic adjustment (GIA) simulations performed in this study are based on model ICE-6G (VM5a) of Peltier et al. (2012, 2015). The Late-Pleistocene ice sheets chronology of model ICE-6G (VM5a) was implemented in the programme SELEN4 (Spada \& Melini, 2019). SELEN4 solves the sea-level equation by taking into account the horizontal migration of shorelines, for the transition from grounded to floating ice and for the effects of rotational feedback on sea level. The sea-level equation was solved using a pseudo-spectral approach with a spatial resolution corresponding to

TABLE 2 Calibrated radiocarbon ages for the three studied facies

\begin{tabular}{|c|c|c|c|c|c|c|c|}
\hline \multirow[b]{2}{*}{ ID } & \multirow[b]{2}{*}{ Dating material } & \multirow[b]{2}{*}{ Depth $(\mathrm{cm})$} & \multirow[b]{2}{*}{ Radiocarbon age } & \multicolumn{4}{|l|}{ Calibration } \\
\hline & & & & 1 sigma & Significant & 2 sigma & Significant \\
\hline Naj1-1 & Charcoal & 78 & $1175 \pm 30$ & 823-892 AD & 0.78 & 774-899 AD & 0.82 \\
\hline Naj3-1 & Shell & 268 & $2400 \pm 30$ & $50-247 \mathrm{AD}$ & 1.0 & $50 \mathrm{BC}-354 \mathrm{AD}$ & 1.0 \\
\hline
\end{tabular}


the maximum harmonic degree $\operatorname{Imax}=256$, on a grid with a spacing of $\sim 40 \mathrm{~km}$.

\section{6 | RESULTS}

\section{1 | Geomorphological and archaeological contexts}

\subsection{1 | Local watershed management}

The alluvial geomorphological features such as wadis, alluvial fans and flood plains underscore the high potential risk of flooding and debris flow by flash flooding events during winter and autumn on this specific lowland coast. One of the most important factors mediating runoff power discharge to downstream areas is soil permeability (Sampson, 2016). The upstream lithological units are made of low permeability gypsum marls with sandstone interlayers. The gypsum marl unit contains soluble evaporation minerals and fine-grained sediment (silt and clay). This leads to a decrease in permeability and soil strength against erosion (Heshmati et al., 2013). As a result, a huge amount of sediment was reworked to downstream areas through the stream channels, leading to coastal progradation at the base level. Decreases in slope angles and sudden changes in watershed bedrock types from marl (soft bedrock) to sandstone (hard bedrock) mean that the runoff cannot be evacuated. Abrupt stream channel disruption has led to the formation of alluvial fans north of the ancient site at the base level (Figure $4 b$ ).

To protect the city from flash floods, a cemented dike was erected at the end of the stream, with an aim to reduce runoff energy. The water was channelled in an artificial watercourse that was excavated into the bedrock (Figures 2 and 4c,d). The watercourse directed runoff water to the city via a channel, which passed north of the city. During flooding events, muddy sediment passed through the artificial channel (Figure 4e). The runoff water, containing high amounts of dissolved salts, was channelled to the city for industrial purposes.

\subsubsection{Analysis of the urban area}

We could not find any preserved ancient buildings to analyse the urban fabric, due to extensive erosion and destruction by industrial activities and also the absence of archaeological excavations. On the basis of the remains of building walls, it is possible to infer the widespread use of rubble and cooked gypsum for construction (Figure 3).

South of the zone, we identified 15 almost rectangular embankments, probably used as ponds (Figure 3 ). The ponds were fed by an ancient canal. The canal lies on a gentle west-to-east slope and it has distribution canals between the ponds. The runoff water was stopped behind the dike to prevent outflow to the sea. The trapped water entered the canals and moved through them under gravity.
Different elevations between each row of ponds (from north to south) facilitated this flow. Saturated water was collected in the wet seasons and gypsum was subsequently precipitated through evaporation processes during warm and arid seasons. The resulting gypsum crystals were collected for baking in the furnaces of the artisanal area.

\subsection{3 | Evaluation of site damage}

In terms of archaeological erosion, the study site has been significantly damaged by anthropogenic processes during last 20 years. Satellite images and field observations demonstrated that anthropogenic activities have destroyed much of the ancient urban and artisanal areas. According to Esmaeili Jelodar's (2011) report, the destruction of the ancient site predates recent industrial developments. Unfortunately, the same trend is observed in the other ancient Zones $A$ and $C$. But a newly discovered site (Site D) is almost void of recent human intervention (Figure 5).

\section{2 | Litho- and biostratigraphy}

The core station is $+4.5 \mathrm{~m}$ above the current sea level. In the coastal stratigraphy, two main marine (A) and brackish (B) environments have been identified. The facies were differentiated according to the lithology, sediment properties (mineralogy and grain morphology), ostracod assemblages and grain size. The core was divided into four facies (Figure 6).

\subsection{1 | Unit A: Marine facies and RSL fluctuations}

The first marine facies is observed at $267-280 \mathrm{~cm}$, where yellowish-brown silty sand changes to the dark brown sandy silt with negatively skewed, poorly sorted sediment and high OM content. The ostracod species Cytherella sericea, Chrysocythere corralloides, Keijella karwarens, Asymmetricythere indoiranica, together with Hemicytheridea paiki and Keijella neaki, are consistent with a marine subtidal environment. The sandy portions have two different sources: (i) the first is quartz with bar-like shape with rounded edges, linked to an interbasin source, and (ii) the second comprises fine to very fine subrounded quartz, biotite sheets, imported by aeolian processes. The interbasin portions are generally aggregated by evaporitic minerals with rounded edges. The absence of euryhaline species and sudden changes in facies without a transitional facies show a marine transgression over a disconformity surface. This transition from playa (1-A) to marine (2-C) conditions was concurrent with increasing MS concurrent with imported iron (biotite) into the environment by wind and emerging Venericythere darwinii, H. paiki and K. neaki species. The finest sediment grain size, with the highest amounts of MS and $\mathrm{OM}$ in the marine environment, is observed at $278 \mathrm{~cm}$. 

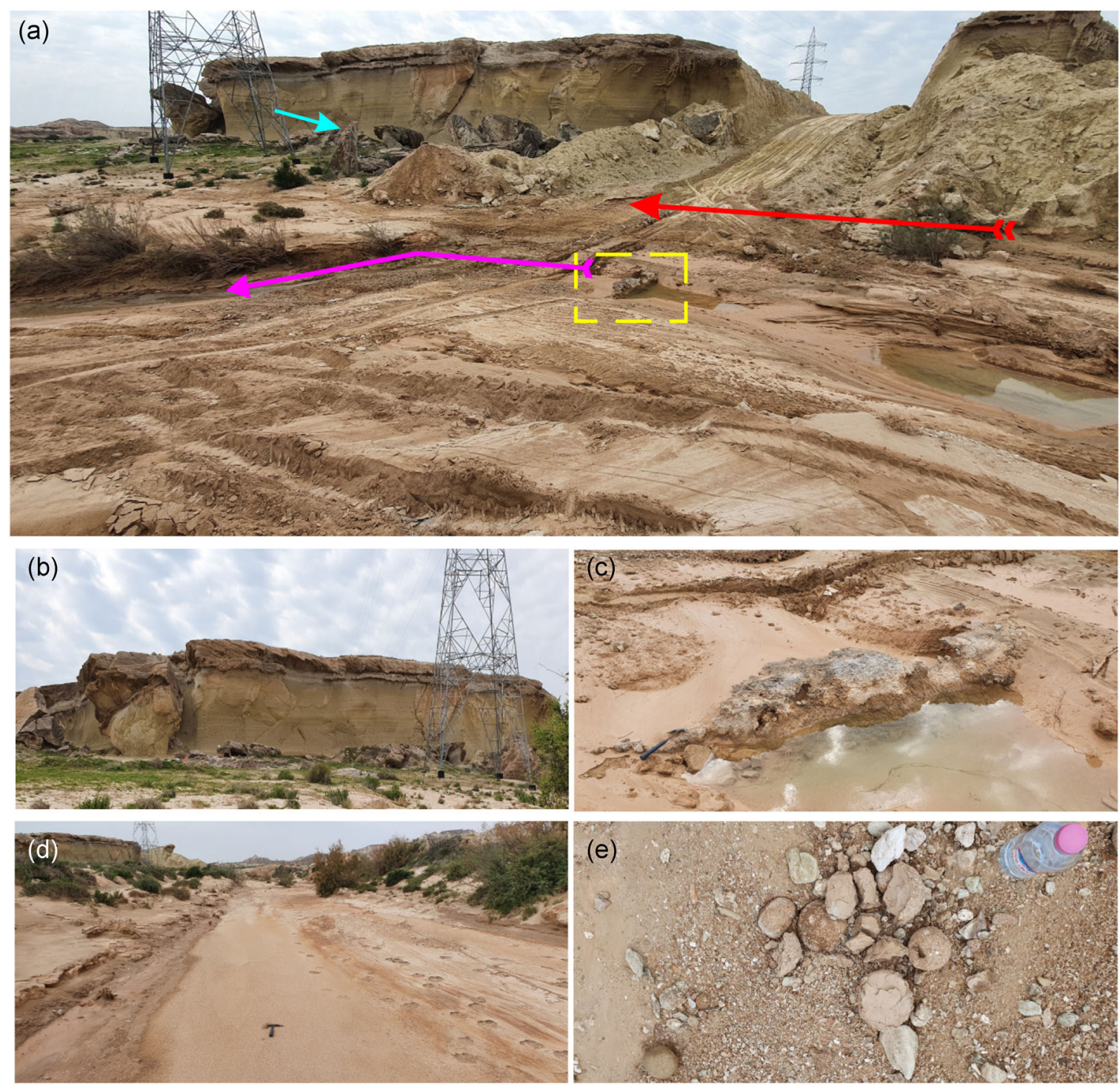

FIGURE 4 (a) The red arrow represents an old ephemeral river direction that has led to erosion of the marl section of the rock. The cyan arrow and (b) show eroded sandstone rock from the outcrop. The yellow dashed line and (c) show the man-made dike used to reduce floodwater velocity and sluice water along a narrow artificial channel shown in purple. (d,e) Artificial channel over sandstone bedrock. Mud balls are formed due to the reworking of mud pieces over the hard bedrock [Color figure can be viewed at wileyonlinelibrary.com]

An assemblage of euryhaline ostracods Cyprideis torosa and the marine lagoonal $C$. sericea and Venericythere papuensis species may indicate a minor oscillation of the RSL and the extension of shallow marine conditions (2-B). A marked increase in sediment grain size due to an increasing sand fraction (13.3\%-71.75\%), decreasing sorting, OM and MS suggest a higher energy environment at $250-267 \mathrm{~cm}$ between $50 \mathrm{BC}$ and $354 \mathrm{AD}$ (Table 3). An upward increase in sediment grain size continues to $235-250 \mathrm{~cm}$, where the mean size is $2.2 \varphi$ with nearly symmetrical skewness. Improved sorting in the yellowish brown sand is consistent with stable environmental energy. A significant decrease in $C$. torosa and the high abundance of $C$. sericea, Cerallicythere adenensis, Cistacythereis sp., Alocopocythere reticulata, indoaustralica species, in addition to abundant joined juvenile bivalves, are consistent with a marine environment (2-C). At $225-235 \mathrm{~cm}$, a decrease in mean grain size and a sandy texture was accompanied by improved sorting and positive skewness concomitant with a high-energy setting. These data testify to the onset of permanent longshore currents leading to the creation of sandbars. The abundance of $C$. torosa shows relative instability in the coastal environment. Nevertheless, other species such as $C$. sericea (marine lagoonal), Asymmetricythere whatleyi, Lankacythere elaborara, Corallicythere adenensis, Moosella striata, Chrysocythere keiji (coastal) and $K$. karwarens (subtidal) indicate the extension of the marine (2-C) setting. Also, high MS values indicate inputs of iron-rich minerals such as biotite to the environment through wind processes. This transgressive facies represents a lower shoreface facies with shoreface ridges. The ridges, comprising fine to coarse sands, are attributed to longshore transportation of tidal inlets, which are mainly active for cross-shore mobility during marine transgression (McBride \& Moslow, 1991). 
(a)

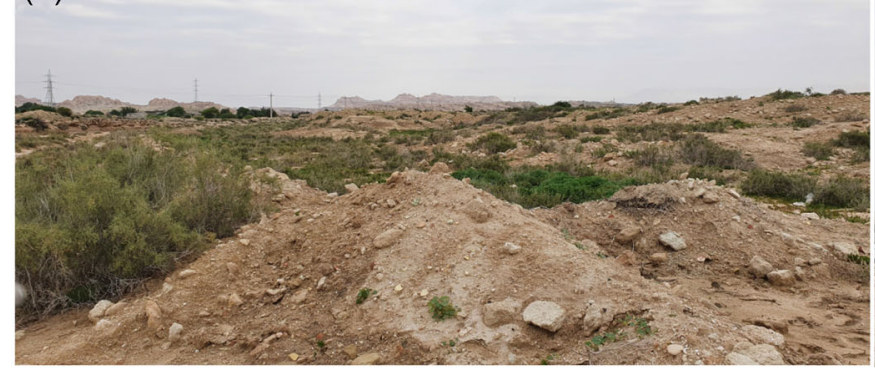

(c)

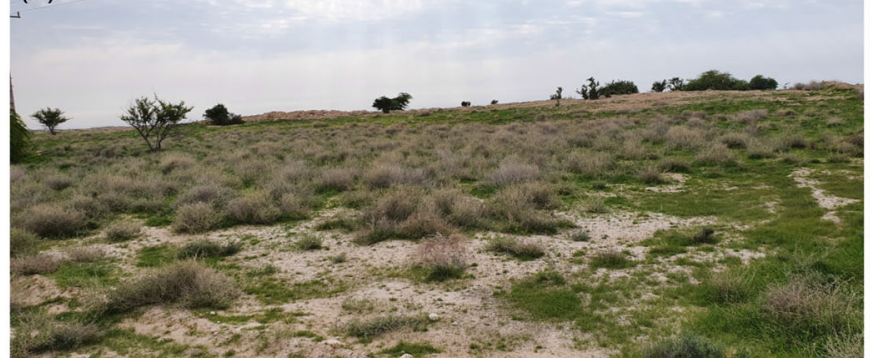

(b)
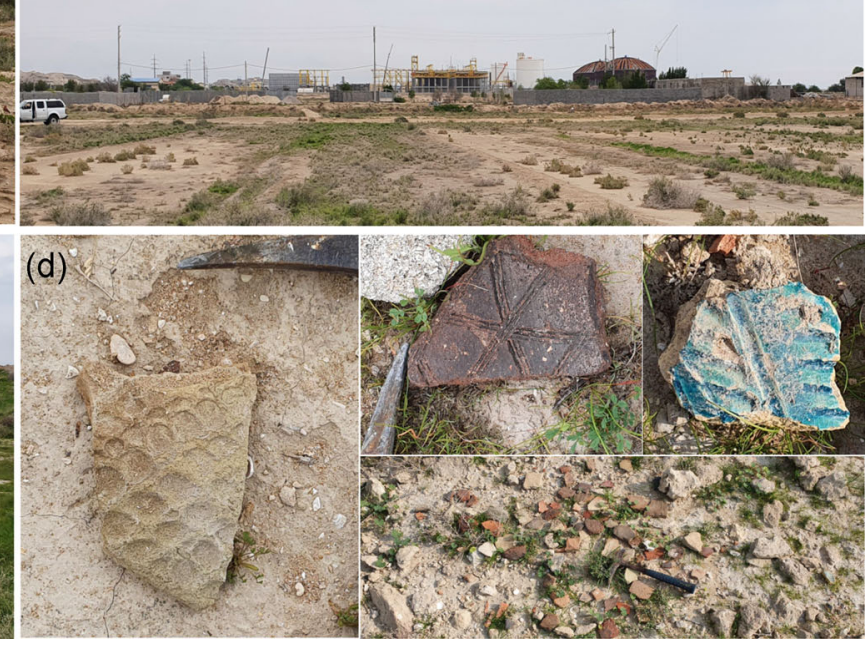

FIGURE 5 (a) View of part of the bulldozed ancient site of Bataneh (Zone B); (b) industrial construction in ancient Zone C. (c,d) Newly discovered ancient Zone D containing late Sassanid-early Islamic ceramics [Color figure can be viewed at wileyonlinelibrary.com]

OM enrichment in the silty sand sediment and a decline in sorting indices, positive skewness values and a significant reduction in single ostracod valves confirm a gradually decreasing energy setting. Marine lagoonal ostracod species (C. sericea and V. papuensis), together with $C$. torosa and coastal species (Paijenborchellina venosa,
Paranesidea handel), indicate a shifting environment from 2-C to 2-A $(212-225 \mathrm{~cm})$. These data translate a backshore facies with oscillations in marine inundation and vegetation growth. A return to muddy deposition is identified within the sandy sediment of shore ridges or cheniers.

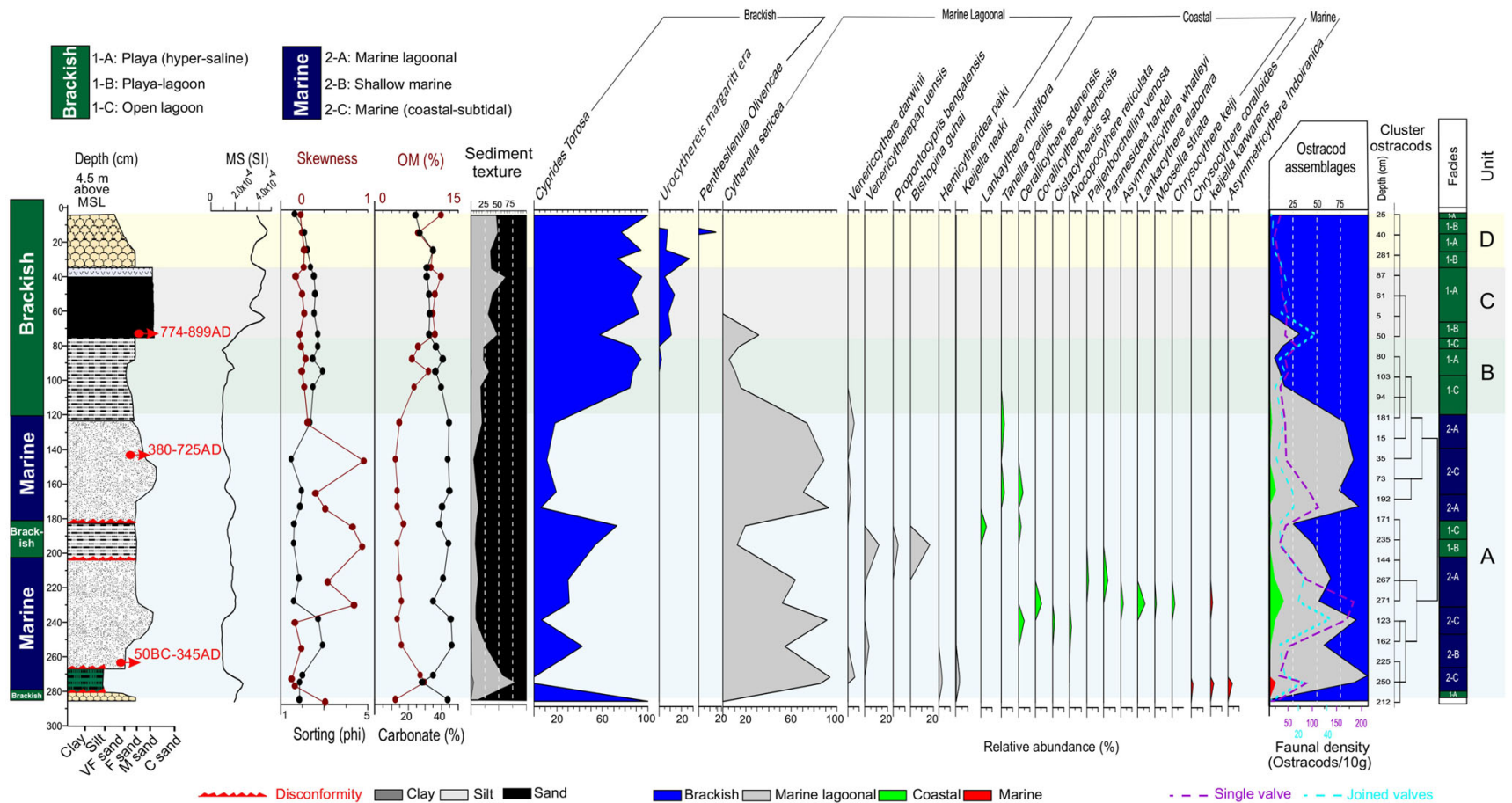

FIGURE 6 Sediment stratigraphy, biostratigraphy, chronology and sedimentology of the studied core. Six main palaeoenvironments are defined [Color figure can be viewed at wileyonlinelibrary.com] 
TABLE 3 RSL oscillation comparison between reconstructed sea level via GIA model and the obtained results from facies analysis at Siraf and Bataneh

\begin{tabular}{|c|c|c|c|c|c|}
\hline Location & Facies & Sea-level index & Sea level $(m)$ & Calibrated age & GIA sea level (m) \\
\hline Siraf & Anthropogenic horizon & Core depth & $-2.8 \pm 0.5$ & $44 B C-459 A D$ & $0.9 \pm 0.2$ \\
\hline Bataneh & Coastal zone & Ostracods- sandbars & $-2.3 \pm 0.4$ & $50 B C-345 A D$ & $0.8 \pm 0.1$ \\
\hline Siraf & Anthropogenic horizon & Core depth & $-2.8 \pm 0.5$ & $113 A D-478 A D$ & $0.7 \pm 0.2$ \\
\hline Bataneh & Marine lagoonal environment & Ostracods & $-0.8 \pm 0.5$ & 380 AD-725 AD & $0.6 \pm 0.1$ \\
\hline
\end{tabular}

Abbreviations: GIA, glacial isostatic adjustment; RSL, relative sea level.

The first brackish facies is between marine lagoonal facies (2-A) at 192-202 (1-B) and 181-192 (1-C). The ostracod assemblages and sediment textures in the two yellowish-brown sands are different from the other brackish facies. The main difference is the presence of a tiny crust of syn-sedimentary marine cement fractions (beachrock) in these facies. Mean sorting and skewness indices imply increasing environmental energy (increasing sediment grain size with increasing sorting index from the base to top). C. torosa is the main species in both facies, but its abundance increases from the base to top (57.17\%-73.17\%). The beachrock fractions generally contain fine to very fine sand portions resulting from wind influxes during cementation. The cementation occurred during increases in seawater injection within the sediments via increasing wave and tidal energy (increase wind events). Storm waves could be responsible for developing coarser sediment over marine lagoonal facies and creating chenier structures.

At 181-192 cm, when hypersaline species abundances were high due to the RSL expansion, $C$. torosa is observed with marine lagoonal and coastal (2-C) species such as C. sericea, V. papuensis, Propontocypris bengalensis and Bishopina guhai. There is a mixture of rounded and angular sands with angular to subrounded beachrock fractions consistent with RSL expansion and increasing sediment transport with coastal processes.

Marine lagoonal species (C. sericea and $V$. darwinii) and low abundances of $C$. torosa appear again at $171-181 \mathrm{~cm}$ (facies 2-A). An increase in sediment grain size, sorting index and skewness evokes an RSL expansion and developing backshore facies (2-C) at $144-162 \mathrm{~cm}$. A variety of ostracod species are observed in this facies, including brackish (C. torosa), marine lagoonal (C. sericea and V. darwinii) and marine (Tanella gracilis, Cerallicythere adenensis) taxa.

The RSL started to fall during 380-725 AD, and a marine lagoonal environment (2-A) with $C$. sericea and $V$. darwinii species was created at $123-144 \mathrm{~cm}$ (Table 3). Decreasing sediment grain size, together with increasing sorting index and positive skewness values, shows that deposition occurred in a confined environment without biotite sheets. The absence of biotite suggests a shift in wind directions and probably the onset of NW Shamal winds. RSL reduction led to the deposition of the second brackish facies at $123 \mathrm{~cm}$. By this time, accessibility to the northwest ports had been restricted via Ras-e-Motaf and the unique morphological shape of Shatt-al-Arab palaeo-delta (Pourkerman et al., 2020). Navigation through Ras-e-Motaf became dangerous after the onset of summer time NW Shamal wind during ca. 650 AD. The highest wave energy, with an anticlockwise whirlpool under storm conditions, occurred in the Ras-e-Motaf. This part of the Persian Gulf is known as Iran's 'Bermuda triangle' and it has been an area of numerous shipping accidents (Kamranzad et al., 2013).

\subsection{2 | Unit B: Open lagoon with freshwater flux}

The second brackish facies at $103-123 \mathrm{~cm}$ is characterised by a decrease in the marine lagoonal species $C$. sericea (15.63\%) and an increase in the hypersaline species $C$. torosa, which represents $84 \%$ of total valves. Plant remains are also observed and they constitute the first evidence of freshwater flux in the open lagoon facies (1-C). The sediment changes to dark brown silty sand with light grey sandy silt lenses at $94-103 \mathrm{~cm}$. The lenses contain charcoal and plant remains. The presence of the macrofossil Neogastropoda olividae points to the extension of an open lagoon (1-C) setting.

Increasing mean sediment grain size, negative skewness, decreasing MS, increasing sorting index and the appearance of aggregated fine sand at $87-94 \mathrm{~cm}$ are consistent with changes in the environmental setting. C. torosa attains relative abundances of $94 \%$, and the percentage of single valves and joined valves is $30.4 \%$ and $69.5 \%$, respectively. This facies represents a hypersaline playa environment (1-A) with aeolian influxes. Dark brown silty sand with a rounded sand fraction, nearly symmetrical skewness and extremely poor sorting $(4.3 \varphi)$ is observed at $80-87 \mathrm{~cm}$. The presence of the marine lagoonal species $C$. sericea (14.06\%), together with $C$. torosa (85.9\%) and gravels, suggests limited access to the sea. C. sericea attains relative abundances of up to $20 \%$ with Urocythereis margaritifera and C. torosa at $75-80 \mathrm{~cm}$, suggesting an open lagoon environment (1-C). This facies represents the last evidence of marine species after isolation from the sea due to coastal uplift.

\subsection{3 | Unit C: Anthropogenic zone}

An anthropogenic facies is observed at $40-75 \mathrm{~cm}$, where brownishblack sediment contains ceramics, charcoal and gypsum (crystals with charcoal inclusions, baked and amorphous) (Figure 7). Radiocarbon 
dating reveals that the first human traces occurred between 774 and $899 \mathrm{AD}$ (Table 3). MS recorded maximum magnetic contents (3.8 and $4.48 \times 10^{-4} \mathrm{SI}$ ) and is positively correlated with OM. The anthropogenic facies begins with poorly sorted silty sand with positive skewness. It gradually changes to very poorly sorted sandy silt with nearly symmetric skewness. The grain size fines upwards, with a decreasing sorting index. MS and OM values continue to increase up to $40 \mathrm{~cm}$, where the euryhaline species $C$. torosa attains $94.87 \%$. A thin layer of amorphous white gypsum is deposited at the top of the unit and constitutes a marker for the termination of the anthropogenic facies.

\subsection{4 | Unit D: Lagoon}

The anthropogenic horizon is covered by aeolian sediments that contain yellowish-brown rounded to subrounded silty sand, gypsum crystals, plant remains, charcoal and a small fraction of ceramics with rounded edges (consistent with reworking by wind action from the exposed archaeological site). Sorting ranges from very poor to poor $(3.46-1.24 \varphi$ ). The sediment sorting improves from the base to top. The sedimentology suggests environmental oscillation changes between playa (1-A) and playa lagoon (1-B) in the man-made evaporation ponds. Lagoonal species such as $U$. margaritifera and Penthesilenula olivencae, together with $C$. torosa, are consistent with variable salinities, typical of playa lagoon environments (1-B). The abundance of ostracod shells decreases from the base to the top. A maximum shell abundance is observed at $5-7 \mathrm{~cm}(1-A)$, where $C$. torosa is the single species. At $35-37$ and $15-17 \mathrm{~cm}$ (1-B), the percentage of $C$. torosa decreases and $U$. margaritifera comprises a quarter of the shells. MS varies between 3.32 and $4.66 \times 10^{-4} \mathrm{SI}$, with a maximum value logged at $15-17 \mathrm{~cm}$, where carbonate content and mean sediment size decrease.

\section{7 | DISCUSSION}

RSL changes in the Persian Gulf are controlled by eustatic sea-level rise, basin subsidence and local uplifts. During the Holocene, the axial zone of the Persian Gulf experienced twofold subsidence, followed by a rapid sea-level rise, especially in the central basin (Uchupi et al., 1999). The central basin hosts many active salt diapirs along deep $\mathrm{N}-\mathrm{S}$ extensional faults and tear fault systems originating in the Hormuz salt formation (Jahani et al., 2007, 2017). Correlations between growth of the Darang salt pillow and RSL fall suggest probable impacts of halokinesis in driving RSL oscillations. During the Persian Gulf highstand (3340-2620 BC), the lower Khuzestan plain experienced several RSL oscillations with short periods (Heyvaert \& Baeteman, 2007). By contrast, a rapid RSL fall occurred in Abu Dhabi during a short period after a highstand (Lokier et al., 2015) and reached below the current sea level by 510-780 AD. Therefore, disparate RSL histories in the north and south of the Persian Gulf appear to result from different tectonic settings and fault systems.

Halokinesis has a direct effect on RSL oscillations via the Persian Gulf axial zone subsidence and localised uplift through the fault systems. As a result, our reconstructed RSL is not correlated with the ICE-6G (VM5a) model for the study sites. Although the model shows a continuous fall, the studied facies record three RSL oscillations. The duration between each oscillation was correlated with the modelled sea-level position. An increasing water column in the central basin floor can lead to increasing crustal mobility in coastal areas.
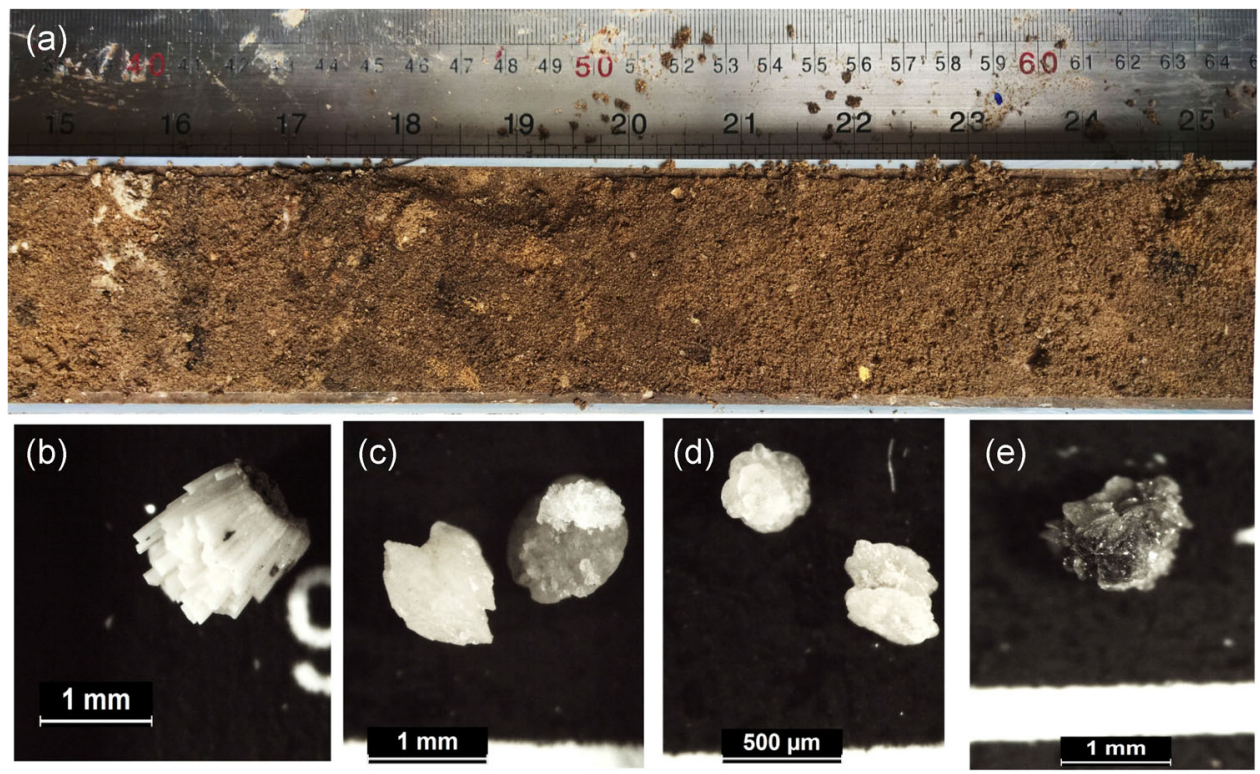

FIGURE 7 (a) Anthropogenic section of the studied core with evaporation minerals of different crystal morphologies. This section ends with gypsum crystals at $38-40 \mathrm{~cm}$. (b) Needle aragonite; (c-e) different crystal shapes of gypsum with black organic matter inclusions [Color figure can be viewed at wileyonlinelibrary.com] 
Meanwhile, the time interval between the lowstand and the ensuing highstand decreased. The Darang salt anticlinal recorded 3.7 $\pm 0.4 \mathrm{~m}$ uplift by the second lowstand.

RSL in the Persian Gulf is an important factor for ancient harbour location. Rishar (Rev Ardeshir) and Apologus were two important Sassanid harbours in the northwest of the Persian Gulf (Le Strange, 1905; Whitehouse \& Williamson, 1973). Apologus was a riverine harbour located at Shatt-al-Arab, and Rishar is situated on the Bushehr coastal peninsula. The archaeological evidence shows that the port of Bushehr was connected to Kazirun and Shiraz via a road used for the export of commodities to other regions. It was the nearest port to Fars and it made Rishar an important port (Boucharlat \& Salles, 1981). The first water column reduction had negative impacts on the Rishar harbour operation due to its coastal morphology (Figure 1). The same trend is observed in other Zone I ancient harbours (Mahroyan, Ceniz, Jenaba). This problem of harbour accessibility provided an opportunity for Apologus to replace them. Apologus maintained its importance in maritime trade until the early Abbasid Caliphate (750-1260 AD), which coincided with the second RSL reduction. Then, in the first century of Islam, the main harbours shifted from Apologus (Ubulla) to Siraf (Wilson, 2011).

The first seawater column reduction was also concurrent with the foundation of a defensive outpost with a port at Siraf (Whitehouse \& Williamson, 1973), but maritime trade flourished at Apologus. It could be related to maintaining sea level due to the Karun-Tigris-Euphrates delta subsidence and local uplift (Uchupi et al., 1999). Seawater intrusion to the river channel during high tide increased the water depth for ocean-going navigation. It was favourable to Apologus's maritime trade until the late Sassanid Empire (ca. 450-650 AD). During the Sassanid to early Islamic (50 BC-950 AD) periods, the settlement density reached its maximum in Mesopotamia (Lawrence et al., 2016).

An unconformity above subtidal facies could be a result of rapid seawater oscillation. The water column reduction is correlated with the first evidence of anthropogenic traces at Siraf. RSL rise and developing coastal facies were concurrent with the progradation of marine facies over the first Sassanid anthropogenic horizon at Siraf (50 BC-550 AD) (Figure 8).

The second RSL oscillation coincided with changes in sediment origin after an increase in summer northwest winds around 650 AD and a second phase of anthropogenic traces at Siraf (150-450 AD) (Pourkerman et al., 2020) (Figure 8). This period was concurrent with dune reactivation and a peak in the aeolian deposition in the southeast of the Persian Gulf (Parker \& Goudie, 2008; Stokes et al., 2003) and the development of marshland deposits over tidal channels in the southern part of the Khuzestan plain (Heyvaert \& Baeteman, 2007).

During the Umayyad to early Abbasid dynasties (650-750 AD), there was a decrease in maritime trade in the Gulf (Potter, 2009). This could be related to sudden changes in both RSL reduction and economic/political changes. A decreasing river water column at Shatt-alArab, following RSL fall and decreases in precipitation, led to accessibility problems at Apologus for ocean-going vessels (Al-Istakhri, 1870). By contrast, risk of navigation in the western part of the Persian Gulf was accelerated during summer by the interaction of Persian Gulf

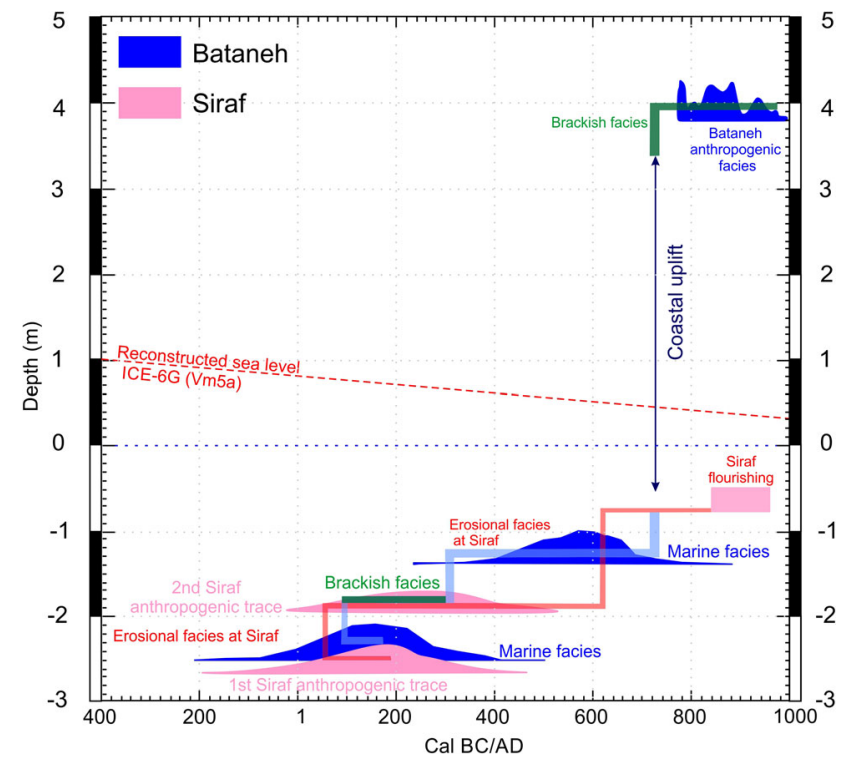

FIGURE 8 Age-depth model of the Bataneh facies changes, Siraf anthropogenic traces (Pourkerman et al., 2020) and ICE-6G (VM5a) model. This figure shows the impacts of relative sea-level changes and coastal uplift on Siraf's ancient harbour and Bataneh [Color figure can be viewed at wileyonlinelibrary.com]

water circulation and summer Shamal winds at Ras-e-Motaf (Pourkerman et al., 2020). The Shamal wind generates the highest wave energy with an anticlockwise whirlpool (under storm conditions) at Ras-e-Motaf. This area is famous as being Iran's 'Bermuda triangle' and has been a zone of numerous shipping accidents (Kamranzad et al., 2013). The environmental changes led to economic decline at the head of the Persian Gulf around the 10th century AD (Adams, 1965; Wilkinson, 2003).

Bataneh is located in Zone II where halokinesis has had direct effects on the coastal zone and its hinterland. Darang salt diapiric fold and the geomorphological changes in the hinterland were concurrent with a second RSL fall. The rapid transition from open lagoon to brackish facies translates to a rapid uplift of $\mathrm{ca}$. $3.7 \pm 0.4 \mathrm{~m}$ in the coastal zone due to the Darang salt pillow growth. The uplift changed local watershed geomorphology and fluvial directions. These changes caused the abrupt cessation of the stream channel and extending alluvial fans. The stream sourced in the sensitive gypsum marl unit was a great risk for the ancient city. The city was protected by embankment walls and a dam with an artificial canal over hard bedrock that safely channelled floodwater through the city.

One of the reasons that Bataneh port failed was probably coastal uplift. The expansion of Siraf brought rapid urbanisation of the city and local towns. This rapid expansion necessitated new building materials. At this time, cooked gypsum was widely used as cement, in plaster motifs and in decorative objects. Therefore, gypsum very soon became a noteworthy commercial good. Several ancient gypsum mines existed around Siraf. Traditional mining necessitated time and labour for the extraction and transfer of raw gypsum. As a result, gypsum became expensive. New gypsum extraction methods via evaporation pools at Bataneh led to cheaper 
gypsum. The method took advantage of Bataneh's geomorphological traits and gypsum units present in the local geology.

\section{8 | CONCLUSIONS}

Two RSL falls have been recorded. The first event (510-780 AD) had negative impacts on harbours in the western basin such as Rishar. There were only minor impacts on Apologus due to crustal mobility between 150 and 650 AD. The second RSL fall event at 770-900 AD and the onset of summer time Shamal wind since 650 AD were coincident with important harbours shifted to the central part of the Persian Gulf. Both Bataneh and Siraf were suitable locations. Siraf was surpassed by Bataneh due to its stable rocky coast. Uplift at Bataneh led to changes in geomorphological features in the hinterland and the city was exposed to flooding risk. The runoff water that originated from marl gypsum units was harnessed by a dam and an artificial canal and sluiced to the city through safe channels. The runoff water was collected in evaporation ponds and left to precipitate as gypsum during the warm and arid summers. The gypsum trade brought prosperity to the city. Coastal uplift was a key factor in reducing port accessibility and therefore activity at Bataneh. The location of Najirum's harbour is still unclear.

Recent oil and gas infrastructure has destroyed large parts of the ancient sites. These structures are also at risk from natural hazards such as coastal uplift and flooding. South Pars offshore oil and gas field has led to the expansion of several petrochemical companies along the coastal. They have had direct and indirect impacts on the destruction of ancient sites. Further geoarchaeological studies are required at waterfront sites of the Persian Gulf, because many sites are being destroyed by modern developments, present RSL rise and coastal erosion (Pourkerman et al., 2018).

\section{ACKNOWLEDGMENTS}

This study was supported by the Center of International Scientific Studies and Collaborations (CISSC), the Iran National Science Foundation (INSF Grant Number: 94-44915), the French Embassy in Iran, Campus France (PHC GUNDISHAPUR 2016-2017, Project Number: 35630QH) and Labex OT-Med (ANR-11-LABX-0061). Radiocarbon datings were funded through the project 'LIA HAOMA' supported by the Centre National de Recherche Scientifique (CNRS, France). The study was also supported by Iran National Elite's Foundation and National Science Foundation Grant 94-44915. Giorgio Spada is funded by an FFABR (Finanziamento delle Attività Base di Ricerca) grant of the MIUR (Ministero dell'Istruzione, dell'Università e della Ricerca) and by a DiSPeA (Dipartimento di Scienze Pure e Applicate of the Urbino University) research grant.

\section{ORCID}

Majid Pourkerman (D) https://orcid.org/0000-0002-9307-1689 Abdolmajid N. Beni (D) https://orcid.org/0000-0002-0825-1539

\section{REFERENCES}

Adams, R. M. (1965). Land behind Baghdad: A history of settlement on the Diyala Plains. University of Chicago Press.

Al-Istakhri. (1870). In M. J. de Goeje (Ed. \& Trans.), Kitab Al-Masalik wa-alMamalik.

Aqrawi, A. A. (2001). Stratigraphic signatures of climatic change during the Holocene evolution of the Tigris-Euphrates delta, lower Mesopotamia. Global and Planetary Change, 28(1-4), 267-283.

Arhan, D., Pavlopoulos, K., \& Fouache, E. (2020). Holocene relative sealevel variations and archeological implications, Abu Dhabi western region, United Arab Emirates. Arabian Journal of Geosciences, 13(6), 1-16.

Azarian, M. (2013). Bataneh ancient site systematically survey in order to identification location of Najirum ancient harbour [Farsi] (Master's thesis). Tarbiat Modares University, Tehran, Iran.

Balkhi, I., "Fārsnāmeh." Le Strange, G., \& Nicholson, R. A. (1984). Tehrān: Donyā-ye Ketāb.

Beck, A., Philip, G., Abdulkarim, M., \& Donoghue, D. (2007). Evaluation of Corona and Ikonos high resolution satellite imagery for archaeological prospection in western Syria. Antiquity, 81(311), 161-175.

Benjamin, J., Rovere, A., Fontana, A., Furlani, S., Vacchi, M., Inglis, R. H., Galili, E., Antonioli, F., Sivan, D., Miko, S., Mourtzas, N., Felja, I., Meredith-Williams, M., Goodman-Tchernov, B., Kolaiti, E., Anzidei, M., \& Gehrels, R. (2017). Late Quaternary sea-level changes and early human societies in the central and eastern Mediterranean Basin: An interdisciplinary review. Quaternary International, 449, 29-57.

Berberian, M. (1995). Master "blind" thrust faults hidden under the Zagros folds: Active basement tectonics and surface morphotectonics. Tectonophysics, 241(3-4), 193-224.

Beydoun, Z. R. (1991). Arabian plate hydrocarbon geology and potential, a plate tectonic approach. American Association of Petroleum Geologists, Studies in Geology, 33, 77.

Boucharlat, R., \& Salles, J. F. (1981, January). The history and archaeology of the Gulf from the fifth century BC to the seventh century AD: a review of the evidence. In Proceedings of the Seminar for Arabian Studies. Seminar for Arabian Studies.

Caspers, E. C. D. (1971). New archaeological evidence for maritime trade in the Persian Gulf during the Late Protoliterate period. East and West, 21(1-2), 21-44.

Daryaee, T. (2003). The Persian Gulf trade in late antiquity. Journal of World History, 1-16.

Daryaee, T. (2009). The Persian Gulf in late antiquity: the Sasanian era (200-700 CE), The Persian Gulf in History (pp. 57-70). Palgrave Macmillan.

Delile, H., Mazzini, I., Blichert-Toft, J., Goiran, J. P., Arnaud-Godet, F., Salomon, F., \& Albarède, F. (2014). Geochemical investigation of a sediment core from the Trajan basin at Portus, the harbour of ancient Rome. Quaternary Science Reviews, 87, 34-45.

Driesch, A., \& Dockner, A. (2002). Animal exploitation in medieval Siraf. Iran, based on the faunal remains from the excavations at the Great Mosque (seasons 1966-1973). Bonner zoologische Beitrage, 50(3), 227-248.

Esmaeili Jelodar, M. (2011). A propose for Identification of Najirum ancient harbour according to the early-Islamic texts and archaeological survey [Farsi]. Journal of the Persian Gulf, 3, 129-159.

Folk, R. L. (1954). The distinction between grain size and mineral composition in sedimentary rock nomenclature. Journal of Geology, 62(4), 344-359.

Folk, R. L., \& Ward, W. C. (1957). Brazos River bar [Texas]; a study in the significance of grain size parameters. Journal of Sedimentary Research, 27(1), 3-26.

Hansman, J. (1968). The problems of Qūmis. Journal of the Royal Asiatic Society, 100(2), 111-139.

Hassanpour, J., Yassaghi, A., Muñoz, J. A., \& Jahani, S. (2020). Salt tectonics in a double salt-source layer setting (Eastern Persian Gulf, 
Iran): Insights from interpretation of seismic profiles and sequential cross-section restoration. Basin Research, 33, 159-185.

Heiri, O., Lotter, A. F., \& Lemcke, G. (2001). Loss on ignition as a method for estimating organic and carbonate content in sediments: Reproducibility and comparability of results. Journal of Paleolimnology, 25(1), 101-110.

Heshmati, M., Majid, N. M., Jusop, S., Gheitury, M., \& Abdu, A. (2013). Effects of soil and rock mineralogy on soil erosion features in the Merek watershed, Iran. Journal of Geographic Information System, 5, 248-257.

Heyvaert, V. M. A., \& Baeteman, C. (2007). Holocene sedimentary evolution and palaeocoastlines of the Lower Khuzestan plain (southwest Iran). Marine Geology, 242(1-3), 83-108.

Ibn, H. (1965). In J. H. Kramers (Ed. \& Trans.), Kitab Surat al-Ard. Bibliotheca Geographorum Arabicorum.

Ibn, H., \& de Goeje, M. (1873). Al-Masālik wa'I-Mamālik.

Jahani, S., Callot, J. P., de Lamotte, D. F., Letouzey, J., \& Leturmy, P. (2007). The salt diapirs of the eastern Fars Province (Zagros, Iran): A brief outline of their past and present, Thrust Belts and Foreland Basins. Springer.

Jahani, S., Hassanpour, J., Mohammadi-Firouz, S., Letouzey, J., de Lamotte, D. F., Alavi, S. A., \& Soleimany, B. (2017). Salt tectonics and tear faulting in the central part of the Zagros Fold-Thrust Belt, Iran. Marine and Petroleum Geology, 86, 426-446.

Jiménez-Munt, I., Fernàndez, M., Saura, E., Vergés, J., \& Garcia-Castellanos, D. (2012). 3-D lithospheric structure and regional/residual Bouguer anomalies in the Arabia-Eurasia collision (Iran). Geophysical Journal International, 190(3), 1311-1324.

Kamranzad, B., Etemad-Shahidi, A., \& Chegini, V. (2013). Assessment of wave energy variation in the Persian Gulf. Ocean Engineering, 70, 72-80.

Kassler, P. (1973). The structural and geomorphological evolution of the Persian Gulf. In B. H. Purser (Ed.), The Persian Gulf, Holocene carbonate sedimentation in a shallow epicontinental sea (pp. 11-32). Springer.

Konert, G., Afifi, A. M., Al-Harjri, S. A., \& Droste, H. J. (2001). Paleozoic stratigraphy and hydrocarbon habitat of the Arabian Plate. GeoArabia, 6(3), 407-442.

Lambeck, K. (1996). Shoreline reconstructions for the Persian Gulf since the last glacial maximum. Earth and Planetary Science Letters, 142(1-2), 43-57.

Lawrence, D., Philip, G., Hunt, H., Snape-Kennedy, L., \& Wilkinson, T. J. (2016). Long term population, city size and climate trends in the Fertile Crescent: A first approximation. PLoS One, 11(3), e0152563.

Le Strange, G. (1905). The lands of the Eastern Caliphate: Mesopotamia, Persia, and central Asia, from the Moslem conquest to the time of Timur. University Press.

Lidour, K., Béarez, P., Charpentier, V., \& Méry, S. (2020). The prehistoric fisheries of Akab Island (United Arab Emirates): New insights into coastal subsistence during Neolithic in eastern Arabia. The Journal of Island and Coastal Archaeology, 15(1), 80-103.

Lokier, S. W., Bateman, M. D., Larkin, N. R., Rye, P., \& Stewart, J. R. (2015). Late Quaternary sea-level changes of the Persian Gulf. Quaternary Research, 84(1), 69-81.

Marriner, N., Kaniewski, D., Morhange, C., Flaux, C., Giaime, M., Vacchi, M., \& Goff, J. (2017). Tsunamis in the geological record: Making waves with a cautionary tale from the Mediterranean. Science Advances, 3(10), e1700485.

Marriner, N., \& Morhange, C. (2007). Geoscience of ancient Mediterranean harbours. Earth-Science Reviews, 80(3-4), 137-194.

Marriner, N., Morhange, C., Boudagher-Fadel, M., Bourcier, M., \& Carbonel, P. (2005). Geoarchaeology of Tyre's ancient northern harbour, Phoenicia. Journal of Archaeological Science, 32(9), 1302-1327.
Marriner, N., Morhange, C., Flaux, C., \& Carayon, N. (2017). Harbours and ports. Encyclopedia of Geoarchaeology, 382-403.

Marriner, N., Morhange, C., \& Goiran, J. P. (2010). Coastal and ancient harbour geoarchaeology. Geology Today, 26(1), 21-27.

al-Mas'udi, A. L. H. (1962). Les prairies d'or. Trans. C. Barbier de Meynard, Pavet de Courteille, and Charles Pellat, Société asiatique.

McBride, R. A., \& Moslow, T. F. (1991). Origin, evolution, and distribution of shoreface sand ridges, Atlantic inner shelf, USA. Marine Geology, 97(1-2), 57-85.

McClure, H. A., \& Vita-Finzi, C. (1982). Holocene shorelines and tectonics movements in Eastern Saudi Arabia. Tectonophysics, 85, 37-43.

Morhange, C., Laborel, J., \& Hesnard, A. (2001). Changes of relative sea level during the past 5000 years in the ancient harbor of Marseilles, Southern France. Palaeogeography, Palaeoclimatology, Palaeoecology, 166(3-4), 319-329.

Myers, A. (2010). Field work in the age of digital reproduction: A review of the potentials and limitations of Google Earth for archaeologists. SAA Archaeological Record, 10(4), 7-11.

Parker, A. G., \& Goudie, A. S. (2008). Geomorphological and palaeoenvironmental investigations in the southeastern Arabian Gulf region and the implication for the archaeology of the region. Geomorphology, 101(3), 458-470.

Paul, A., \& Lokier, S. W. (2017). Holocene marine hardground formation in the Arabian Gulf: Shoreline stabilisation, sea level and early diagenesis in the coastal sabkha of Abu Dhabi. Sedimentary Geology, 352, 1-13.

Peltier, W. R., Argus, D., Drummond, R., \& Moore, A. W. (2012). Postglacial rebound and current ice loss estimates from space geodesy: The new ICE-6G (VM5a) global model. In AGU Fall Meeting Abstracts.

Peltier, W. R., Argus, D. F., \& Drummond, R. (2015). Space geodesy constrains ice age terminal deglaciation: The global ICE-6G_C (VM5a) model. Journal of Geophysical Research: Solid Earth, 120(1), 450-487.

Potter, L. (2009). The Persian Gulf in history. Springer.

Pourkerman, M., Marriner, N., Morhange, C., Djamali, M., Alizadeh, H., \& Tofighian, H. (2019). Tracking shoreline erosion of "at risk" coastal archaeology (Persian Gulf: Sassanid-Islamic heritage relics in southeastern Bataneh, Iran). Final conference-What kind of environmental transition for the Mediterranean region? Marseille, France. http://www.otmed.fr/final-conference-what-kindenvironmental-transition-mediterranean-region-october-14-16-2019

Pourkerman, M., Marriner, N., Morhange, C., Djamali, M., Amjadi, S., Lahijani, H., Naderi Beni, A., Vacchi, M., Tofighian, H., \& ShahHoesseini, M. (2018). Tracking shoreline erosion of "at risk" coastal archaeology: The example of ancient Siraf (Iran, Persian Gulf). Applied Geography, 101, 45-55.

Pourkerman, M., Marriner, N., Morhange, C., Djamali, M., Spada, G., Amjadi, S., Vacchi, M., Lahijani, H., Esmaeili Jelodar, M., Tofighian, H., \& Naderi Beni, A. (2020). Geoarchaeology as a tool to understand ancient navigation in the northern Persian Gulf and the harbour history of Siraf. Journal of Archaeological Science: Reports, 33, 102539.

Priestman, S. (2007). The British museum Siraf project. The British Institute of Persian studies. Newsletter no. 32, 5-6.

Sahafi, H., Daghooghi, B., \& Rameshi, H. (2000). Persian Gulf Molluscs Atlas, Iranian Fisheries Research Center.

Saleem, A., Corner, R., \& Awange, J. (2018). On the possibility of using CORONA and Landsat data for evaluating and mapping long-term LULC: Case study of Iraqi Kurdistan. Applied Geography, 90, 145-154.

Sampson, S. E. (2016). The correlation between soil permeability and flooding in the northeast sector of the Dog River watershed. Department of Earth Sciences, University of South Alabama, Alabama. http://www.southalabama 
Snidero, M., Carrera, N., Mencos, J., Butillé, M., Granado, P., Tavani, S., Lopez-Mir, B., Sàbat, F., \& Muñoz, J. A. (2020). Diapir kinematics in a multi-layer salt system from the eastern Persian Gulf. Marine and Petroleum Geology, 117, 104402.

Southon, J., Kashgarian, M., Fontugne, M., Metivier, B., \& Yim, W. W. (2002). Marine reservoir corrections for the Indian Ocean and Southeast Asia. Radiocarbon, 44(1), 167-180.

Spada, G., \& Melini, D. (2019). SELEN4 (SELEN version 4.0): A Fortran program for solving the gravitationally and topographically selfconsistent sea level equation in glacial isostatic adjustment modeling. Geoscientific Model Development, 12(12), 5055-5075.

Stevens, T., Jestico, M. J., Evans, G., \& Kirkham, A. (2014). Eustatic control of late Quaternary sea-level change in the Arabian/Persian Gulf. Quaternary Research, 82(1), 175-184.

Stokes, S., Goudie, A. S., Colls, A. E. L., \& Al-Farraj, A. (2003). Optical dating as a tool for studying dune reactivation, accretion rates and desertification over decadal, centennial and millennial timescales. In A. S. Alsharhan, W. W. Wood, \& A. S. Goudie (Eds.), Desertification in the Third Millenium (pp. 57-66). Balkema.

al-Tabari, A. J. F. M. (1987). The History of al-Tabari II, Prophets and Patriarchs.

Thomas, R. J., Ellison, R. A., Goodenough, K. M., Roberts, N. M., \& Allen, P. A. (2015). Salt domes of the UAE and Oman: Probing eastern Arabia. Precambrian Research, 256, 1-16.

Uchupi, E., Swift, S. A., \& Ross, D. A. (1999). Late Quaternary stratigraphy, paleoclimate and neotectonism of the Persian (Arabian) Gulf region. Marine Geology, 160(1-2), 1-23.

US Geological Survey. (2011). World seismicity maps, Middle East 1990-2006. http://earthquake.usgs.gov/earthquakes/world/seismicity/ m_east.php

Vacchi, M., Ermolli, E. R., Morhange, C., Ruello, M. R., Di Donato, V., Di Vito, M. A., Giampaola, D., Carsana, V., Liuzza, V., Cinque, A., \& Boetto, G. (2020). Millennial variability of rates of sea-level rise in the ancient harbour of Naples (Italy, western Mediterranean Sea). Quaternary Research, 93(1), 284-298.

Warrak, M. (2019). Sedimentary environment and diapirism of the Pleistocene-Holocene deposits of the Zirku salt plug, southern Arabian Gulf. Arabian Journal of Geosciences, 12(13), 397.

Whitehouse, D., \& Williamson, A. (1973). Sasanian maritime trade. Iran, 11(1), 29-49.

Wilkinson, T. J. (2003). Archaeological landscapes of the Near East. University of Arizona Press.

Williams, A. H., \& Walkden, G. M. (2002). Late Quaternary highstand deposits of the southern Arabian Gulf: a record of sea-level and climate change (Special Publications 195, pp. (1), pp. 371-386). Geological Society.

Wilson, A. (2011). The Persian Gulf (Vol. 10). Routledge.

Wood, W. W., Bailey, R. M., Hampton, B. A., Kraemer, T. F., Lu, Z., Clark, D. W., James, R. H., \& Al Ramadan, K. (2012). Rapid late Pleistocene/Holocene uplift and coastal evolution of the southern Arabian (Persian) Gulf. Quaternary Research, 77(2), 215-220.

How to cite this article: Pourkerman, M., Marriner, N., Morhange, C., Djamali, M., Lahijani, H., Amjadi, S., Vacchi, M., Jelodar, M. E., Spada, G., Tofighian, H., \& Beni, A. N. (2021). Late Holocene relative sea-level fluctuations and crustal mobility at Bataneh (Najirum) archaeological site, Persian Gulf, Iran. Geoarchaeology, 1-15.

https://doi.org/10.1002/gea.21860 